\title{
BESZÁMOLÓ A MAGYAR TUDOMÁNYOS AKADÉMIA REGIONÁLIS TUDOMÁNYOS BIZOTTSÁGA 1999. ÉVI TEVÉKENYSÉGÉRŐL
}

1) A Településtudományi Bizottsággal együtt februárban, az MTA székházban sikeres konferenciát rendeztünk a „Településügy helyzete" címmel. A résztvevők száma 70-80 fö között volt. A konferencia állásfoglalást adott közre, amelyet eljutatott a szakmai szervezetekhez.

2) A Bizottság 1999 áprilisában az MTA Stratégiai Kutatások keretében folyó, „A területfejlesztési program tudományos megalapozása" c. program kutatásainak bemutatására konferenciát rendezett Budapesten, az MTA Székházban. A konferencia délutánján pódiumbeszélgetést rendeztünk a ,Regionális tudomány - Regionális politika együtt és külön-külön" címmel, ahol vezető kutatók és politikusok mondták el véleményưket. A sikeres tanácskozás résztvevöinek száma 100-120 fö között volt (az ismertetést lsd. Tér és Társadalom 1999. 1-2. 191-194.).

3) Júniusban a Bizottság a Dialóg Campus Könyvkiadóval közös könyvbemutatót szervezett Horváth Gyula "Európai regionális politika" és Rechnitzer János "Területi stratégiák" c. monográfiájáról.

4) A Bizottság januárban tartott téli ülésén megtárgyalta Horváth Gyula doktori címre benyújtott pályázatát. Ezen az ülésen került alapos megvitatásra egy dokumentum, amely a „A regionális tudomány, mint önálló diszciplína” címmel került összeállításra. A tagtársak által egyhangúan támogatott memorandumot (Tér és Társadalom 1998. 3. 162-163.) eljutattuk az MTA elnökének, hogy a diszciplína vitában a véleményünket vegyék figyelembe. Eddig nem kaptunk választ a beadványunkra.

5) A Bizottság tavaszi ülésén egy beterjesztést tárgyalt, Pálné Kovács Ilona doktori cselekményre beadott pályázatát. A cselekmény megindítását a bizottság doktori fokozattal rendelkezó tagjai támogatták.

6) A bizottság öszi ülésén megtörtént a tisztségviselök megválasztása (Tér és Társadalom 1999. 3. 131-132.), illetve megbízás történt az Oktatási Munkabizottság megalakitására (vezető: Buday-Sántha Attila tanszékvezetó egyetemi tanár, Janus Pannonius Tudományegyetem Közgazdaságtudományi Kar). Az Oktatási Munkabizottság novemberben Pécsett ülésezett, megkezdődött az oktatási tematikák feltérképezése, a tananyagok összegyüjtése, az oktatási programok egyeztetése.

7) A Bizottság munkájáról a szakmai közönséget rendszeresen tájékoztatjuk a Tér és Társadalom folyoiraton keresztül, mivel az MTA Regionális Tudományos Bizottsága hírei ơnálló rovatban jelennek meg.

8) Örömünkre szolgál, hogy 1999-ben két doktori címre érkezett be pályázat. Az egyik a védéssel sikeresen lezárult (Horváth Gyula), a másiknak a nyilvános vitára történỏ elökészítése megtörtént (Pálné Kovács Ilona).

9) A taglétszámban 10-15\%-os növekedés tapasztalható, ami döntően a sikeres rendezvényeknek, illetve a téma iránti növekvő érdeklödésnek köszönhetö.

Györ, 2000. január 28.

Rechnitzer János DSc. elnők 